\title{
Organising Academia Online
}

\author{
Thomas Köhler, Christoph Lattemann, and Jörg Neumann
}

\begin{abstract}
Research on organisational arrangements of scholarly networks in both e-learning and e-research is located at the intersection of different theoretical justifications and developmental contexts such as organisational theory, computer science, education science and media informatics. However, there is still a lack of research on the organisational context of e-learning arrangements and its impact on collaboration in academic communities. E-learning research shows that the integration of electronic media in scientific communities negatively impacts their effectiveness and causes conflicts within communities. Research networks however are far less investigated as there is not direct didactic focus on how to collaborate. Recent theories on organisational design, virtual organisations and governance provide concepts for organising e-collaboration more effectively. Managerial instruments such as direct control of results and behaviours need to be supplemented or even replaced by concepts of social control; typically trust and confidence become the central mechanisms for the new forms of inter- and intra-organisational coordination. This paper starts with concepts. Then, to exemplify the organisational coordination mechanisms in scholarly e-communities, the authors critically discuss and reflect on these organisational arrangements and managerial concepts for two higher education portals and one research network in Germany. The conclusion is that, just as previous research has confirmed for educational networks, governance within academic networks relies heavily on the functionality of social and communicative forms of control.
\end{abstract}

Keywords Research network $\cdot$ Education portal $\cdot$ Virtual organisation • Governance $\cdot$ Social control $\cdot$ Science collaboration $\cdot$ Scholarly collaboration Online community

T. Köhler $(\varangle)$

Department of Education, Technische Universität Dresden, Dresden, Germany e-mail: thomas.koehler@tu-dresden.de

C. Lattemann

Department of Business and Economics, Jacobs University, Bremen, Germany e-mail: c.lattemann@jacobs-university.de

J. Neumann

Media Center, Technische Universität Dresden, Dresden, Germany

e-mail: joerg.neumann@tu-dresden.de 


\section{Introduction}

The central aim of this article is to identify forms of organisational governance (social, output, or behavioural control) that are suitable for effective e-collaboration in scientific communities. Are "e-learning" and "e-science" fundamentally different things? Specifically, does e-learning concern teaching, and e-science, research? This is factually correct, but from an organisation theory perspective, not a sufficient criterion for differentiation. Above all, the clientele at issue here is the same: the teaching and research staff of universities. In addition, both activities are carried out within the same institution. In this respect, comparison is not only possible, it is mandatory.

Our evaluation is based on both a review of the relevant literature and empirical studies, some of which were conducted by the authors. Following the classification of virtual organisations, the main characteristics of organising academic activities are presented and validated through suitable institutional examples.

\section{E-Learning Organisation: Media Integration as Organisational Development}

\subsection{Online Technologies in Higher Education}

The integration of new media in educational settings has been intensively discussed in academic research and education for about 15 years. Various forms of online, distance, and blended learning have been implemented and tested. After a series of tentative, rather experimental tests to integrate new Internet technologies and electronic media in teaching processes, the management of students and eventually the teaching itself, we now see the results in the forms of web-based tutorials (WBT), virtual learning environments (VLE) and more recently in massive open online courses (MOOC).

With respect to developments in the online learning arena, in 1999 the German expert group on Higher Education Development by New Media predicted the higher education landscape would be as follows (cf. Köhler et al. 2010):

1. Global education providers and platforms offer worldwide accessible online courses.

2. Traditional universities are in competition with private online providers, in particular with corporate universities, and students use the opportunities of the global education market.

3. In order to survive in this competitive situation, many colleges have joined together in networks and offer common learning opportunities, while universities are jointly offering their academic programs together under the umbrella of a virtual university. 
4. Student services are provided by facilitators and tutors, and less by classical university teachers, because more than $50 \%$ of students study online.

As of today, these predictions can only partly be confirmed. However, besides the established Open Universities like the British Open University or the German Fernuniversität Hagen, new global education providers such as the edX, Coursera or Udacity are emerging and become more relevant with the increasing need for lifelong learning and with growing numbers of students seeking for flexible online learning. Nevertheless, they still only play a niche role in higher education so far. But it is no surprise that the Centre for Higher Education Development (Hener and Buch 2006) concluded more than a decade ago that "[i]n academic education [...] uses of digital media in teaching and learning and integration of information technologybased administrative services have become widely established. Key questions of the future are seen especially in the interlinking of different services" (p. 2).

\subsection{Virtualisation in Higher Education}

Academic research has dealt with the use of Internet-based technology in teaching for many years (see, e.g., Lievrouw et al. 2000; Issing and Klimsa 2003, 2010). While initial claims were rather didactic ("classroom technology"), virtualised educational scenarios (VLEs, MOOCs, etc.) are of increasing interest nowadays. The concept of virtualisation is being used more and more often to describe the essential features and expectations of information and communication technologies (ICT) and multimedia, and to document the change. What exactly is behind it? Features of virtualisation described by Köhler et al. (2010) include the facts that students no longer meet their seminar leaders personally and that neither they nor the lecturers need to borrow books from the library. Researchers submit their conference abstracts, and expert opinions on other posts, via an Internet portal, while heads of research projects identify potential research partners in a database-without having ever met in person before. All in all, universities and virtual academies cooperate by uploading teaching content to a joint learning management system to be used by students from other institutions. In sum, such a far-reaching change in the educational landscape has established itself in less than 15 years and is on the verge of becoming the standard. However, acceptance by the teaching staff, especially at universities, is rather low; for example, professors in Toronto went on strike in 1997 and have managed to keep their teaching offline until today. Similarly, a study published by the Centro Nacional de Estadística, Geografía e Informática Mexico in 2004 (INEGI 2004) explained that $70 \%$ of professors in Mexico protested against the use of ICT in education. Their main reason was and perhaps still is the form of presentation of course content when using ICT in formats like PowerPoint and LaTeX. The distinctly reluctant behaviour of university staff is illustrated, for example, by the words of a professor from education sciences "you have to operate well didactically [...] and a part of this is the whole computer nonsense" (Misoch and Köhler 2005, p. 1). In the same 
way, the dean of the engineering department at a leading German university stated in 2015 that "the nightmare is graduates who no longer draw without a computer, no more writing". ${ }^{1}$ The prevailing opinion is that this leads to a very impersonal design of seminar rooms and lecture halls, whereby students may lose their communication and personal contact with each other. Respondents continue to believe ICT should only be used in education to communicate data and not to communicate between people, nor do they see it as a new academic format or alternative for formation, though it may be used in addition to a classroom setting.

Hence, pivotal questions remain unanswered. What will the campus of 2025 look like? Which organisational models of e-learning and e-science collaboration will prevail? Despite the aforementioned reluctance in academia, other developments are observable. For example, online learning is proliferating in media-related disciplines; topics such as artificial intelligence, telemedicine and distance learning, MOOCs and open science are frequently and extensively discussed as powerful new opportunities for improving academic activity in general (Pscheida et al. 2014; Lattemann and Khaddage 2013).

Our first conclusion is that ICT has changed (academic) education. As the above examples illustrate, this change is not limited to education, academic teaching and learning. This raises the question of what exactly the virtualisation of education means. As early as 1999, Landfried, then President of the German Rectors' Conference, described unlimited access to stocks of knowledge independent of time and space; yet this knowledge is disconnected (separated) from physical institutions and, in particular, individuals (Landfried 2009). What is meant by this double separation? To answer this, it is important to analyse what is virtualised, which is more than the learning objects or knowledge content. In fact, relations (micro- and macro-social, but also those between learners and learning object) can be virtualised as well as knowledge, sometimes both at the same time.

\section{Change of Organisational Theories and Paradigms}

What has been known from both management and operational practice for a long time (cf. Frindte et al. 2000) now also appears to apply to education: ICT is becoming more important in managing organisational processes, and these infrastructures are becoming permanent. But these processes vary significantly, raising the question of the ideal configuration of technology and organisation. The first research to address this issue introduced new ICT to control operational processes in knowledge cooperation. Munkvold (2003) set up such a heuristic that can be transferred to the educational context almost directly. He divided the "implementation of collaboration technologies" into four sub-areas, the (1) organisational context, (2) implementation project,

\footnotetext{
${ }^{1}$ This quotation was taken from an anonymised interview by the author.
} 
(3) technological context and (4) implementation phase. Similarly, with explicit reference to the introduction of online learning in higher education when used as dimensions of change, Euler et al. (2004) proposed the following five dimensions: (1) economic dimension, (2) pedagogical-didactic (educational) dimension, (3) organisational/administrative dimension, (4) technical dimension and (5) sociocultural dimension.

Are these theories based on economics or technology? Neither. Organisation and organisational culture are central to change. With this assessment, the authors align with a strand in the German educational research tradition (Neumann and Schütte 2008 ) that is gaining ground but still rather new. This broadens the academic perspective on the use of media, which was previously dominated primarily by cognitive (psychology), teaching (pedagogy), education-oriented (educational science) or even technological (computer science, etc.) approaches. An organisational perspective adds a social and management science-based momentum, and macro-social perspectives. After 2005 more research programmes in Germany sought to meet the need for such an approach, including New Media in Education II or the later Digitisation Initiative (2014). In education and media studies, where approaches based on organisation studies, education science, or media economics are preferred, researchers are frequently challenged to take these approaches.

Just after 2010, based on the concept of openness - used when coining the terms of OER and MOOC - many became convinced that the technology used for university operations would be revolutionised. Within the next decade, it is expected that students will no longer attend lectures or work in a lab, but will join professors' research activities online, whenever and wherever they want. Academic knowledge will be tailored, or transferred from mass production to mass customisation. So what is the core of the "digitisation of teaching" or the "advent of information and communication technologies in the university"? Germany's former Minister of Science, Bulmahn (2004, p. 5), argued that "the new media in the combination of computer and Internet [will penetrate] all social and economic sectors [and will release] a fundamental structural change" combined with unprecedented speed of market globalisation. Ortner and Nickolmann (1999) stressed that the success of open universities will force conventional universities to adopt innovations in teaching organisation, such as distance learning, on-campus students as independent learners, modular course structures and the enrolment of mature part-time students. This goes along with changing forms of social micro-study, from online learning communities (Kahnwald and Köhler 2005) to more complex flexible online knowledge organisations (Köhler et al. 2003).

To speed up the new media restructuring of higher education, the Federal Ministry of Education and Research (BMBF) has targeted the existing New Media in Education Programme and the 2004 re-bid. The first phase of the programme from 2000 to 2004 aimed to develop high-quality e-learning content and concepts for mobile learning, and to put them into regular practice, particularly in undergraduate studies. These developments were intended to be available from 2005 and to be sustained and broadened by two conveyor lines. Conveyor line (A) was for projects in an interdisciplinary and university-specific context, called "e-learning integration". This is 
about developing organisational infrastructure and about changing management to develop utilisation of the opportunities provided by ICT innovation potential in the field of teaching, learning, and exams to universities systematically and sustainably. Conveyor line (B), for projects in a university-wide and primarily subjectspecific context, referred to as "e-learning transfer", was to lead to new organisational concepts and business models for services, related to the production and use of online learning primarily supporting professional and technical areas (cf. BMBF, 2004, all translations from German by the authors). By 2010, most of these projects were completed. What impact did the targeted re-organisation of online learning in German universities have?

\subsection{The Research Framework: Virtual (Educational) Organisations}

In view of the different organisational theories applicable to online teaching and learning in a university context, including its structural and procedural commonalities, the following issues should be noted. At the institutional level, online learning is integrated into the organisational structure of the university. This requires sufficient integration of external service providers. Figure 1 presents the value chain of e-learning from a university perspective, including the internal and external partners at the Technische Universität Dresden in 2008.

The e-learning value chain shows that teaching and learning in an electronically mediated environment is multifaceted and involves various stakeholders. Because of the various partners involved, the organisational concept shows many characteristics of a virtual organisation with loosely coupled partners (external content providers, platform providers, external and internal instructors and students, etc.). Hence, universities which provide online learning arrangements must also follow, or at least adopt, mechanisms of virtual organisations. They must change their structures from their traditional departmental separation towards more process-oriented, open and collaborative organisational settings.

These kinds of new virtual organisations are primarily shaped by their virtual character and are limited by their lack of "real" organisational boundaries. This applies to all organisational aspects: the location, bonds and stability of the organisation. Such a virtual organisation is "multisite, multi-organisational and dynamic" (Snow et al. 1999).

As shown by Köhler and Schilde (2003), virtual organisations can differ greatly in terms of size, durability or stability. Furthermore, various forms of virtual organisation and cooperation are described in theory and can be observed in practice, under an equally large number of names (network, cluster, virtual team, virtual organisation, etc.). In order to make these phenomena comparable and assign experimental findings, a further differentiation of the term is required. Okkonen (2002) proposed one 


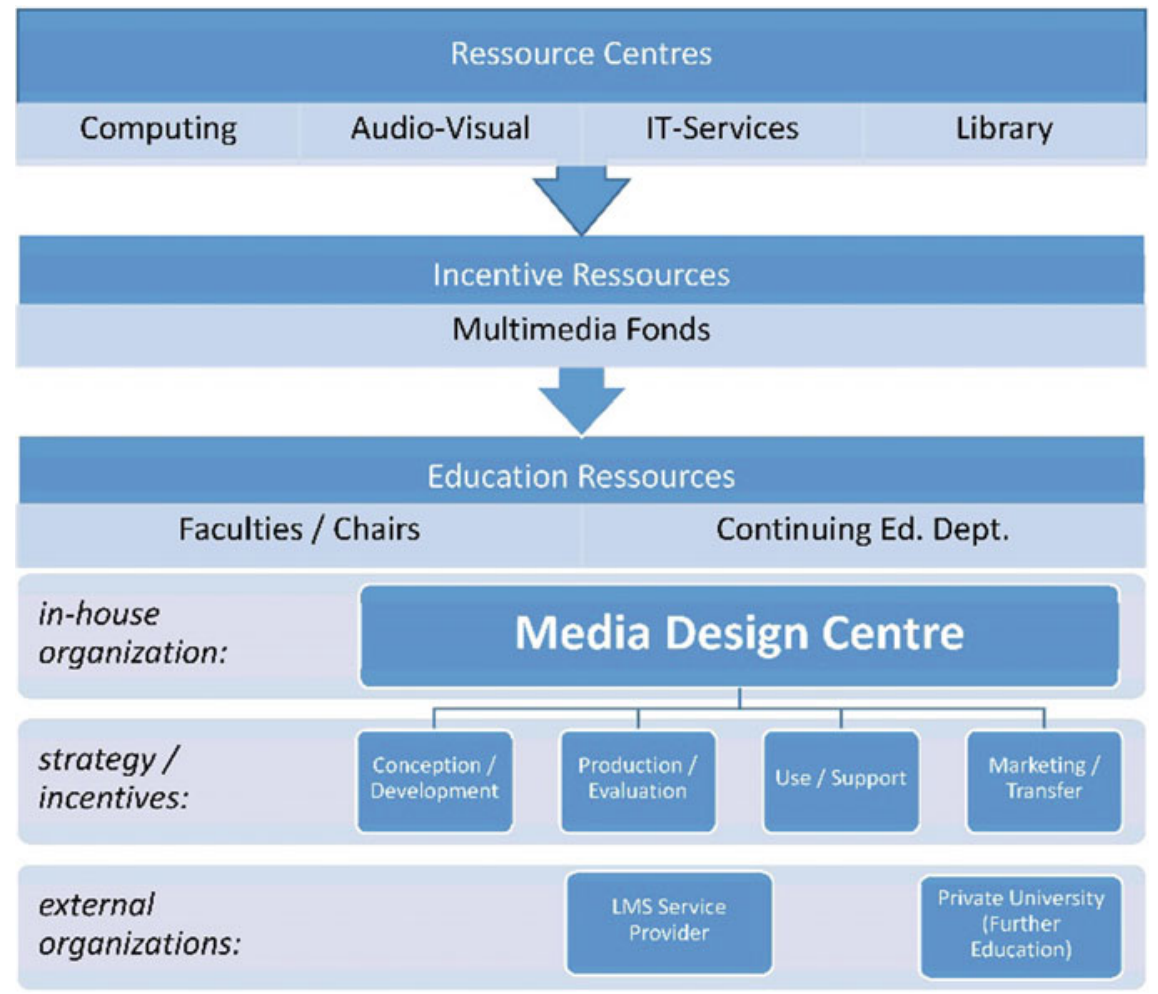

Fig. 1 Organisational framework of online learning using the example of the Technische Universität Dresden (own figure after Neumann and Schütte 2008)

way of doing this, presented by Köhler et al. (2003) as an advanced systematisation of virtualised organisational forms (see the following Table 1).

In the following, two case studies on online learning and one case study on online research are presented and critically discussed from the perspective of virtual organisations.

\subsection{Research Methods}

This paper follows an inductive research approach in order to identify relevant organisational mechanisms in an e-learning institution, based on three case studies. The case study method is selected as it is a common and comprehensive investigative tool for exploring individual, group, organisational or social phenomena (Yin 2013; Bryman and Bell 2011). In this instance, the weaknesses in corporate data security are investigated, in order to reveal potential causes, as discussed in the analysis section. 
Table 1 Differentiated characteristics of virtualised organisational forms (own figure after Okkonen 2002; Köhler et al. 2003)

\begin{tabular}{|c|c|c|c|c|c|}
\hline & Virtual Team & Virtual Project & $\begin{array}{c}\text { Virtual } \\
\text { Organisation } \\
\text { (temporary) }\end{array}$ & $\begin{array}{c}\text { Virtual } \\
\text { Organisation } \\
\text { (permanent) }\end{array}$ & Meta Network \\
\hline Involvement & $\begin{array}{c}\text { organisational } \\
\text { element }\end{array}$ & $\begin{array}{l}\text { function + } \\
\text { overarching }\end{array}$ & overarching & overarching & overarching \\
\hline Membership & small, local & medium sized & usually large & $\begin{array}{l}\text { small, but } \\
\text { scalable }\end{array}$ & large, vague \\
\hline Goal & $\begin{array}{c}\text { teams for specific } \\
\text { tasks }\end{array}$ & $\begin{array}{c}\text { representatives of } \\
>1 \text { organisation } \\
\text { on projects }\end{array}$ & $\begin{array}{c}\text { multiple functions } \\
\text { as reaction to } \\
\text { market }\end{array}$ & $\begin{array}{l}\text { all functions + full } \\
\text { functionality of } \\
\text { working } \\
\text { organisations }\end{array}$ & $\begin{array}{c}\text { multiple functions } \\
\text { in reaction to } \\
\text { market }\end{array}$ \\
\hline Duration & $\begin{array}{l}\text { membership } \\
\text { varies / form } \\
\text { permanent }\end{array}$ & temporary & temporary & permanent & permanent \\
\hline $\begin{array}{l}\text { Information } \\
\text { Technology }\end{array}$ & $\begin{array}{l}\text { Connectivity, } \\
\text { knowledge } \\
\text { remains } \\
\text { separated }\end{array}$ & $\begin{array}{l}\text { collection of } \\
\text { shared data }\end{array}$ & $\begin{array}{c}\text { shared } \\
\text { infrastructure }\end{array}$ & $\begin{array}{c}\text { replaces physical } \\
\text { infrastructure }\end{array}$ & links the networks \\
\hline $\begin{array}{r}\text { Example from } \\
\text { Education }\end{array}$ & $\begin{array}{c}\text { Online learner } \\
\text { team }\end{array}$ & $\begin{array}{c}\text { Student group for } \\
\text { term paper }\end{array}$ & R\&D Project & Education Portal & ResearchGate \\
\hline
\end{tabular}

We have chosen two case studies because the authors of this paper are involved in the projects and they have deep insights. A triangulation approach was utilised as this is "the most desired pattern for dealing with case study data" (Yin 2011). Seminal articles on the case study topics were selected for analysis (Yin 2013).

For this particular example, differing sources have been consolidated to present a comprehensive case study summary, including scientific publications, research reports, and public descriptions on the websites of the chosen institutions. All material was either available publicly or from internal sources. Figures used come from selfdescriptions of those projects - the layout was not changed, but translated.

\section{Case I: Online learning in academic education through the education portal of Saxony (since 2001)}

Since 2001, a university network has been supporting online teaching at public universities in the German federal state of Saxony. After an initial phase with the direct participation of the four universities which comprised this group since 2004, a system corporation, BPS Education Sachsen $\mathrm{GmbH}$, was founded in 2006. In an evaluation of the state of development of online learning at Saxon universities for the Saxon Minister of Science and Art, the German National Centre for Higher Education Development (CHE), stated in 2006 that despite many years of funding by means of the country and the special commitment of many scientists concluded that online media is still used on a relatively small scale. Overall, however, acceptance is increasing among both university staff and students. But Hener and Buch (2006) noted a lack of liability for student usage, sustainability in higher education, and overall management of e-learning in higher education. This has been confirmed by further analyses (Köhler and Ihbe 2006) calling for a more systematic integration of online learning at Germany's largest technical university, the Technische Universität Dresden. In 2007, control of the project passed to the newly established e-learning 


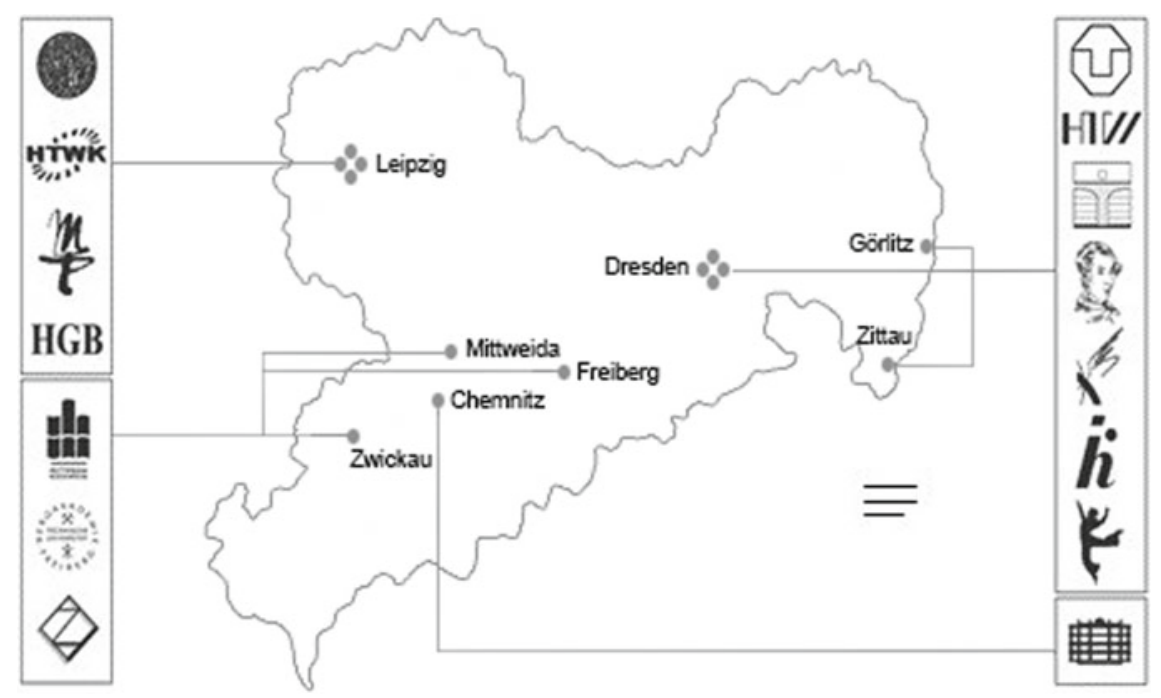

Fig. 2 Model of the education portal of Saxony (cf. https://bildungsportal.sachsen.de/)

working group of the Rector's Conference Saxony. Since then, all public universities in Saxony and two private universities have joined the network. The following Fig. 2 shows the distribution of the educational portal in Saxony as of 2008:

\section{Case II: Online-supported continuous learning in the education portal of Thuringian universities (2000-2013)}

Based on analysis of the need for media-based academic training and organisational structures at and between the universities of Thuringia, and to support more sustainable development of such online training, the (online) education portal for Thuringia was constructed in 2001 (www.bildungsportal-thueringen.de). As a consequence of the above tests, this portal aimed to serve institutional training seekers or their staff, that is, employees who want to selectively add to their skills profile according to their academic or equivalent qualifications or needs. There was already significant potential demand for this when the portal opened. An expert (Stifterverband 2001) estimated that 20,000 of almost 60,000 students of the Distance University of Hagen alone are undergoing a hidden continuing professional development (CPD). The education portal of Thuringia competed with several private CPD providers. This fact should be mentioned because the expectations and attributions of training seekers were influenced by their experiences with these market leaders. Nevertheless, the participating universities have reconfigured themselves on the virtual organisation model, consisting of a core information broker and a network of partners meeting training needs, as in Fig 3.

The education portal of the Thuringian universities remained at the project stage until 2013 and was then closed by the responsible Ministry of Science. 


\begin{tabular}{|c|c|c|c|c|}
\hline PROVIDERS & \multicolumn{3}{|c|}{$\leftarrow$ New impulses for teaching an $d$ learning } & USERS \\
\hline \multirow{2}{*}{$\begin{array}{l}\text { Training } \\
\text { and further } \\
\text { education } \\
\text { offers }\end{array}$} & $\begin{array}{l}\text { Offers } \rightarrow \\
\leftarrow \text { Feedback } \\
\leftarrow \text { Competencies }\end{array}$ & $\begin{array}{l}\text { EDUCATION } \\
\text { PORTAL }\end{array}$ & $\begin{array}{r}\text { Offers } \rightarrow \\
\leftarrow \text { Request for offers }\end{array}$ & $\begin{array}{l}\text { Companies, } \\
\text { institutions, } \\
\text { private }\end{array}$ \\
\hline & Communicate con & & 然 & $\begin{array}{l}\text { interested } \\
\text { parties }\end{array}$ \\
\hline
\end{tabular}

Fig. 3 Model of the education portal of Thuringia (own figure after Schmidt 2002)

\section{Case III: The e-Science Saxony Research Network as a virtual science organisation (since 2011)}

The e-Science Research Network project is a Saxony-wide comprehensive research network of all state universities created to explore approaches and methods in e-science (electronic science). The term e-science describes the different fields of scientific research and development related to the use of computer technologies. While this term is mainly used in Germany and the UK, comparable concepts include "cyber-infrastructure" in the United States or "e-research" in Australia. Currently, the slogan "Science 2.0" frames the discussion, in particular concerning cooperative digital scientific work (Weichselgartner 2010). The thematic range of infrastructures, application architectures, grid and cloud technologies extends to the educational technology known as e-learning. In addition, e-science systems support cooperative research between universities and with the private sector (cf. Ziegler and Diehl 2009). Research in e-science can be subdivided into disciplines such as e-humanities, emedicine or e-engineering. In any case, it extends the scholarly process by integrating e-technologies and methods based thereon. The methodology was found to screen collaborative research activity, but knowledge organisation changed also dramatically and has been systematically underdeveloped by these e-disciplines. Even when research contexts are established or reused, it creates new paradigms, such as the concept of a "living lab". This is user-centred research and open innovation practice, based on research work in multidisciplinary teams. One of the essential activities of these teams is co-creation, bringing together technological innovations and their applications through procedures such as crowdsourcing and crowdcasting. In these driven-by-research community practices, a variety of opinions, needs and knowledge exchanges can be used to brainstorm new scenarios, solutions and applications; yet these may be one-sided (Fig. 4).

Overall, starting with a steady drop in the "half-life of knowledge", the changing demands of industry and the economy, and social changes in the knowledge society, the network partners have developed a new type of research and the accompanying scientific activities. New information and communication technologies can be used in this context, especially to provide, disseminate and use research information, such as laboratory data from simulations using complex aggregate social science information. Thus, media-based networking researchers are characterised by a high degree of flexibility and variability; usage may translate into new contexts through the restructuring of data and their usage. Through the coordinated action of the Saxon 
Fig. 4 Clusters and organisational structure in the e-science Saxony research network

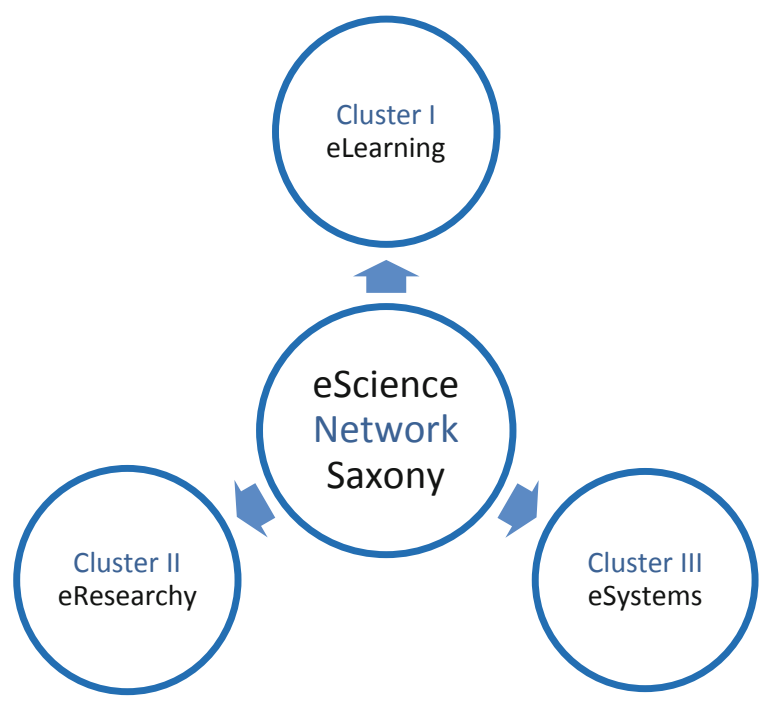

State Ministry for Science and Art and the Federal Republic of Germany, the Saxon universities have achieved an excellent level of "computational science", especially in introducing e-learning support systems (Hener and Buch 2006). Summarised as esciences, the current project focusses on e-business, e-learning and e-systems, which are interwoven holistically at universities in the context of teaching and research.

\section{Discussion and Conclusions}

\subsection{Theoretical Considerations About the Functioning of Virtual Organisations in the Academic Sector}

Recent digitisation initiatives in academia demonstrate the pressing need of a serious discourse about its fundamental principles and practical meaning for the whole sector. In Germany since its launch in 2014, the Higher Education Forum on Digitisation has created an independent national platform to discuss the multiple facets of digitisation in higher education by consulting in six thematic groups on issues surrounding the digitisation of university teaching. ${ }^{2}$

Two decades ago, Malone and Davidow (1992) triggered the discussion about new organisation and management concepts in the economic sciences with their pathsetting contribution "Virtual Corporation". Until that moment, organisational change was marked by various headings such as "Computational Organisation", "Learning

\footnotetext{
${ }^{2}$ http://www.hochschulforumdigitalisierung.de/, retrieved on 15 July 2015.
} 
Organisation", "Organisational Communication", "Society and Internet Development", "Trust Leadership and Decision Making" or "Augmented Reality" (cf. Köhler and Schilde 2003). All approaches share a similar basis: organisational units are reduced to their core competencies and have to cooperate in network-like structures. Complex tasks are realised by a number of independent organisational units or enterprises with complementary skills. This calls into question traditional organisational concepts, as published in governance research. Direct output and behaviour control, which are feasible in traditionally structured enterprises with divisional and functional organisation patterns, are supplemented or even replaced by concepts of social control. In the 1980s, psychological studies of cooperation and communication in virtual communities depicted computer-mediated communication as typically rather anomic in nature (Sproull and Kiesler 1986), less tolerant (Funkhouser and Shaw 1990) and lacking transferable behaviour (Köhler 2003). Postmes (1997) see this analysis as based on the less medium-socialised population of the "early years". Therefore, these findings would be difficult to replicate. However, the cases presented here show that today's changed environment creates completely new ways of medium-socialised collaboration. Once again, the majority are beginners in a new (mediated) organisational culture. Consequently, Lattemann and Köhler (2005) assumed that trust and security of contract would become key factors of cooperation in virtual organisations. This implies that social control becomes a strategic factor in competition among virtual organisations (Barney and Hansen 1994; Krysteck 1997) laying the foundation for new forms of cooperation. Their analysis based on literature review, and our own empirical studies, lead us to observe that the less output and behaviour can be assigned directly to specific individuals, the more important social control of the community becomes.

Our three case studies demonstrate that organisational development towards a networking, virtualised organisational structure can be found in both the academic education and research domains. For both domains, it is obvious that this development is going beyond existing organisational patterns; however, it is not necessarily sustainable, as the closure of the education portal of Thuringian universities after only ten years shows. Is this development merely the interface of a larger organisational change, or the beginning of a new era?

Networking organisations need to move beyond the purely project stage. In all cases, besides new organisational forms we found both close linkage to existing units, including several management instances like steering committees, information offices, and supervisory boards. Neither a classical hierarchy nor a clear linkage to all partners were found in these cases. Structures and opportunities for influencing the processes seem rather soft and depend on functioning communication.

In sum, virtual networks with flexibly aligned partners, who deliver different services and competencies, heavily rely on the coordination of and motivation for social control and trust. Appropriate instruments need to be strengthened. Longestablished norms cannot be adopted because these are either insufficiently developed or simply not applicable — which led to the central question studied by the authors previously: Which governance concept is most efficient in the diverse forms of a virtual organisation? In their study, Lattemann and Köhler (2005) examined the extent 
to which new governance concepts (i.e. social control) may be applied to forms of e-learning (i.e. virtual collaboration) and could propose a classification system for virtual organisations. Already before and after Köhler et al. (2003, 2010) studied the organisation of online learning. In a next step, the focus was directed on research networks as an organizational artefact, their functionality and technology. What can be concluded on how to steer the development and how to govern that functioning of those structures effectively?

\subsection{Forms, Instruments and Mechanisms of Control in Virtual Organisations}

Organisational theory examines traditional forms of governance (behavioural and output control) in detail, mostly uniformly. However, with the establishment of network-like organisational structures, the concept of social control has only recently been subjected to rigorous debate. Only the following forms of governance are considered here:

1. direct governance - inspection of behaviour (behavioural control), such as on the basis of standards won from experiences (Magretta 1998);

2. indirect governance-determination of output based on given goals (output control) (Thomson 1967; Magretta 1998);

3. social governance (social control) - comparison of conformity to certain moral and cultural rules (Ouchi 1979).

As Lattemann and Koehler (2005) argue, instruments of social control can be identified in relation to the level of objective and personnel management (Thomson 1967). Therefore, trust is not related to behavioural and output control mechanisms, as some authors postulate (see, e.g., Manchen and Grote 2000; Bradach and Eccles 1989), but rather supplementary to these (Das and Teng 1998; Ebner et al. 2003). In that sense, traditional control mechanisms and social control describe are different.

How can flexible and light organisational structures be designed and implemented? Based on the above discussion of the literature and cases, trust can be promoted by appropriate social standards and basic institutional conditions. A number of governance instruments can be applied to exercise social control, such as promoting common cultures among networking partners with homogeneous value creation processes, or reviewing and creating similar moral concepts through rituals or ceremonies. The observed networks apply different means, ranging from a project plan to an inter-institutional agreement. This method is particularly suitable for networking partners of a similar size, origin and organisational form (Ouchi 1979), that is, with almost no heterogeneity. Other effective means of social control include operational guidelines (Heck 1999), intensive use of modern and uniform ICT (Köhler 2003; Albers et al. 2002), promoters for public relations and conflict management (Hausschild 1997), job rotation or jointly offered training courses. In the three networks observed here, we found both inter-institutional agreements (such 
as the integrated provision of academic master's programmes) and other measures (such as joint training) for using the platform.

Can the social control model (cf. Fig. 5) developed by Lattemann and Köhler (2005) for learning networks be transferred to research organisations with presumably less standardised activity?

The efficiency of the three governance forms discussed and the possible fields of their application depend upon the nature of the organisational arrangement. The more governance mechanisms are used; the more competencies are required in the process of cooperation. In contrast to traditional enterprises (Type 1 in Fig. 1), where mostly traditional forms of control (behaviour and output control) based on structural governance tools are used to promote coordination (information and communication) and motivation, virtual organisations may adopt concepts of social control with different degrees of intensity.

Virtual teams, virtual projects, temporary virtual organisations and meta-networks are characterised as maximally closed networks with unilateral dependency on the
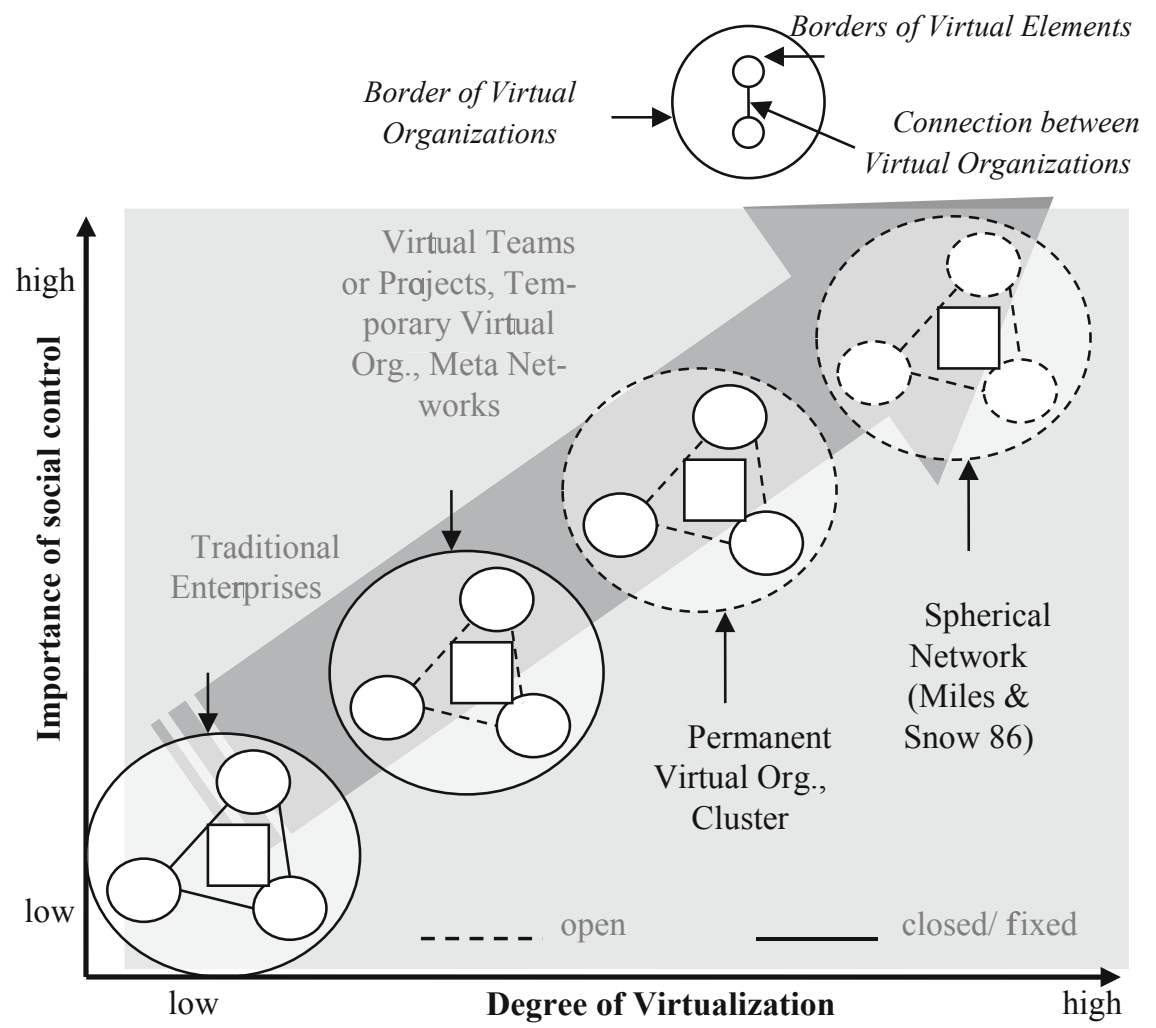

Fig. 5 Social control and organisational virtualisation (figure by authors, cf. Lattemann and Köhler 2005) 
value creation process. The partners provide a wide spectrum of services and products. Such networks do not require a high degree of competency for cooperation. This reflects the fact that social governance tools were not applied intensively in these forms of virtual organisations. Business relations of this type are shaped by marketoriented or structural management instruments, such as a centralised coordinating body based on contractual arrangements (e.g. services or employment contracts). Virtual organisations like this frequently use ICT to collaborate and communicate. This is because both employees of the enterprise and long-term partners are often closely associated. Thus, ICT structures are implemented and do not need to be built up. Also-which is perhaps far more important- these structures do not need to be mediated between the partners, as they are obligatory in most temporary projects. Moreover, members of permanent virtual organisations and clusters need strong collaborative competencies due to their extremely intertwined mutual relations.

A maximum of informal relations is presupposed in spherical networks (Miles and Snow 1986). The roles of individual participants are distributed in a spherical network; resources and/or participants are boundlessly exchangeable. Such structures can be assumed in social networks; however, this article refers to profit-making, not non-profit, environments, so spherical networks are not the focus here. Even its proponents state that this structure cannot be observed in reality (Miles and Snow 1986).

In practice, the extent to which ICT is used to support coordination processes in virtual organisations varies greatly. However, in all virtual organisations, ICT plays a pivotal role; without it, virtual organisation is impossible. Research which was based on a set of unsystematic findings from case studies (Manchen and Grote 2000; Köhler and Schilde 2003; Köhler et al. 2003), recommended that the minimum required ICT support be identified first. The arrangement of information and communication processes determines the complexity of the ICT infrastructure (e.g. enterprise resource planning or e-mail). In less complex virtual organisations (e.g. virtual teams or projects), less sophisticated ICT solutions have been used in academic practice for approximately 20 years. However, in these research organisations, ICTbased groupware solutions were still rather exceptional (Köhler and Röther 2002; Köhler and Schilde 2003). More recently, it has been found out that only a small number of scientists are adopting social media technologies like Mahara, Mendeley or ResearchGate. For example, a Germany-wide survey conducted by Pscheida et al. (2015) found that social media applications such as social networks, microblogs and social bookmarking tools are used by a maximum of $8 \%$ of scientists in a research context. Only in 2020 the influence of the Corona pandemic will perhaps lead to a more massive adoption of such collaboration techniques, but not necessarily in a conscious use.

All in all, organisational models for academic institutions dealing with both education and research need to adapt to organisational models of virtual organisations. Universities and other research institutions have to change in both structure and process within their two main areas-education and research. 


\subsection{Limitations}

Given the recent nature of this study, both the available literature and empirical access to the sectoral development were limited. Firstly, the empirical cases represent developments in German academia only. In the next stage, research must include data from other countries, to develop a more general understanding of organisational dynamics in the academic sector and avoid a national-only explanation.

Some sources, including website communications, were publicly available documents written by legal professionals or corporate representatives. Therefore, the case study may contain less reliable data than that supplied from exclusively academic sources.

Although the authors attempted to adopt a wide range of literature from several sub-disciplines in business, media and education studies, it is difficult to identify whether other researchers intentionally focussed on organisational development or whether this was a by-product of other considerations. Thus, the case made here is largely based on the previous work of the authors.

\section{References}

Albers, S., Bisping, D., Teichmann, K., Wolf, J.: Management virtueller Unternehmen. Research Paper University of Kiel (2002)

Barney, J., Hansen, M.: Trustworthiness as a Source of Competitive Advantages. Strateg. Manag. J. 15, 175-190 (1994)

Bradach, J., Eccles, R.: Price, authority, and trust: from ideal types to plural forms. Ann. Rev. Sociol. 15, 97-118 (1989)

Bryman, A., Bell, E.: Business Research Methods. Oxford University Press, Oxford (2011)

Bulmahn, E.: Vorwort. In: BMBF: Förderprogramm Neue Medien in der Bildung Lehr- und Lernsoftware. Referat Öffentlichkeitsarbeit, Bonn (2004)

Das T., Teng, B.S.: Between trust and control: Development confidence in partner cooperation in alliances. Acad. Manag. Rev. 23, 491-512 (1998)

Ebner, W., Leimeister, J.M., Krcmer, H.: Vertrauen in virtuellen Communities. In: Uhr, W., Esswein, W., Schoop, E. (eds.) Wirtschaftsinformatik 2003, Band II - Medien Märkte Mobilität, Physika: Wiesbaden, p. 619 (2003)

Frindte, W., Köhler, T.: Computervermittelte Kommunikation und Unternehmen - Wirklichkeit und Virtualität?; In: Stahl, H. \& Hejl, P.: Management und Wirklichkeit - Das Konstruieren von Unternehmen, Märkten und Zukünften; Carl Auer Verlag, Heidelberg (2000)

Funkhouser, G.R., Shaw, E.F.: How synthetic experience shapes social reality. J. Commun. 40(2), 75-87 (1990)

Hausschildt, J.: Innovationsmanagement, 2nd edn. Vahlen, München (1997)

Heck, A.: Strategische Allianzen: Erfolg durch professionelle Umsetzung. Springer, Berlin (1999)

Hener, Y., Buch, F.: Evaluation des Bildungsportals Sachsen durch das CHE Centrum für Hochschulentwicklung. CHE, Gütersloh (2006)

INEGI: Statistischer Report; Instituto Nacional de Estadística, Geografía e Informática México. INEGI, Mexico City (2004)

Issing, J., Klimsa, P.: Information und Lernen mit Multimedia: Lehrbuch für Studium und Praxis; 3. vollst. überarb. Aufl. Beltz Psychologie-Verlags-Union, Weinheim (2003) 
Issing, L. J., Klimsa, P.: Online-Lernen. Ein Handbuch für das Lernen mit Internet; 2. Korrigierte Auflage. Oldenbourg Wissenschaftsverlag, München (2010)

Kahnwald, N., Köhler, T.: Aufbau einer Online-Community für die nichtformale betriebliche Weiterbildung. In: Lattemann, C., Köhler, T. (eds.) Multimediale Bildungstechnologien I: Anwendungen und Implementation. Peter Lang Verlag, Frankfurt am Main (2005)

Köhler, T.: Selbst im Netz? Die Konstruktion des Selbst unter den Bedingungen computervermittelter Kommunikation. Westdeutscher Verlag, Opladen (2003)

Köhler, T., Ihbe, W.: Möglichkeiten und Stand der Nutzung neuer Medientechnologien für die akademische Lehre. Überlegungen zur aktuellen Situation an der TU Dresden; Wissenschaftliche Zeitschrift der Technischen Universität Dresden, 1-2 (2006)

Köhler, T., Röther, U.: SAP-R/3 Einsatz durch einen externen Dienstleister im Konzernverbund. unpublished research report for SBI GmbH, Jena (2002)

Köhler, T., Schilde, P.: From project teams to a virtual organization: The case of the education Portal Thuringia. Front. E-Business Res. (2) (2003)

Köhler, T., Neumann, J., Saupe, V.: Organisation des Online-Lernens. In: Issing, L.J., Klimsa, P. (eds.) Online-Lernen. Ein Handbuch für das Lernen mit Internet (2. revised Version). Oldenbourg Wissenschaftsverlag, München (2010)

Köhler, T., Wetzstein, A., Schilde, P.: Möglichkeiten der organisationalen Unterstützung räumlich verteilter Arbeits- und Lernprozesse. In: Enderlein, H., Müller, E. (eds.) Vernetzt planen und produzieren. Universitätsverlag, Chemnitz (2003)

Krysteck, U.: Vertrauen als Basis erfolgreicher strategischer Unternehmungsführung. In: Hahn, D., Taylor, B. (eds.) Strategische Unternehmensplanung - Strategische Unternehmensführung. Stand und Entwicklungstendenzen 7. Aufl. Springer, Heidelberg (1997)

Landfried, K.: Vortrag auf der Hochschultagung der Gewerkschaft Erziehung und Wissenschaft (GEW), Sylt, 3 Sept 2009 (1999/2009)

Lattemann, C., Khaddage, F.: A review of the current status of mobile apps in education. In: Alon, I., Jones, V., McIntyre, J. (eds.) Innovation in Business Education in Emerging Countries. Macmillan-Palgrave, pp. 181-192 (2013)

Lattemann, C., Köhler, T.: Trust or control-governance concepts for virtual organizations. Front. e-Business Res. 3 (2005)

Lievrouw, L.A., Bucy, E., Frindte, W., Gershon, R., Haythornthwaite, C., Köhler, T., Metz, J., Sundar, S.S.: Current research in new media: an overview of communication and technology. In: Gudykunst, W. (ed.) Communication Yearbook 24. Lawrence Erlbaum Publishers, Mahwah (2000)

Magretta, J.: The power of virtual integration: an interview with dell computer's Michael Dell. Harvard Bus. Rev. 76(2), 73 (1998)

Malone, M.S., Davidow, W.H.: The Virtual Corporation: Structuring and Revitalizing the Corporation for the 21st Century. HarperCollins, New York (1992)

Manchen, S., Grothe, G.: Vernetzte Zusammenarbeit von Unternehmen. Ergebnisse aus vier Fallstudien; Research Paper of Institut für Arbeitspsychologie der ETH Zürich (2000)

Miles, R. E., Snow, C. C.: Organizations: New concepts for new forms, in: California Management Review, 28 (3), pp. 62 (1986)

Misoch, S., Köhler, T.: „... man muss gute Didaktik betreiben [...] und da gehört dieser ganze Computerquatsch dazu ..."; Final report on new media usage in teacher training of Potsdam University (2005)

Munkvold, B.E.: Implementation and use of collaboration technologies in a multinational engineering group: the case of Kvaerner. In: Munkvold, B.E. (ed.) Implementing Collaboration Technologies in Industry: Case Examples and Lessons Learned, pp. 109-128. Springer Verlag, Berlin (2003)

Neumann, J., Schütte, T.: An organizational model for e-learning at universities. In: Hannula, M., Koiranen, M., Tommila, J. et. al. (eds.) Proceedings of EBRF 2007. University of Technology, Tampere (2008)

Okkonen, J.: Performance in virtual organisations. Front. e-Business Res. 1, 267-279 (2002) 
Ortner, G., Nickolmann, F.: Socio-Economics of Virtual Universities. Beltz Deutscher Studien Verlag, Weinheim (1999)

Ouchi, W.G.: A conceptual framework for the design of organizational control mechanisms. Manag. Sci. 25(9) (1979)

Postmes, T.: Social Influence in Computer-Mediated Groups. Print Partners Ipskamp, Enschede (1997)

Pscheida, D., Minet, C., Herbst, S., Albrecht, S., Köhler, T.: Nutzung von Social Media und onlinebasierten Anwendungen in der Wissenschaft. Ergebnisse des Science 2.0-Survey und Datenreport Hochschulen 2014. http://nbn-resolving.de/urn:nbn:de:bsz:14-qucosa-163135 (2015). Accessed 1 Nov 2020

Pscheida, D., Albrecht, S., Herbst, S., Minet, C., Köhler, T.: Nutzung von Social Media und onlinebasierten Anwendungen in der Wissenschaft. Erste Ergebnisse des Science 2.0-Survey 2013 des Leibniz-Forschungsverbundes „Science 2.0”, TUD Press, Dresden (2014)

Schmidt, K.: Sonderpublikation anlässlich der Eröffnung des Bildungsportals Thüringen. BP-T, Erfurt (2002)

Snow, C., Lipnack, J., Stamps, J.: The virtual organization: promises and payoffs, large and small. In: Cooper, C.L., Rousseau, D.M. (eds.) The Virtual Organization. Wiley, Chichester (1999)

Sproull, L., Kiesler, S.: Reducing social context cues: electronic mail in organizational communication. Manag. Sci. 32(11), 1492-1512 (1986)

Stifterverband für die deutsche Wissenschaft (Hrsg.): Campus online - Hochschulen, neue Medien und der globale Bildungsmarkt. Stifterverband für die deutsche Wissenschaft, Essen (2001)

Thomson, J.: Organizations in Action. McGraw-Hill, New York (1967)

Weichselgartner, E.: Digitales wissenschaftliches Arbeite in der Psychologie. In: Petermann, F., Koglin, U. (eds.) Abstractband zum 47. Kongress der Deutschen Gesellschaft für Psychologie. Pabst, Lengerich (2010)

Yin, R.K.: Qualitative Research from Start to Finish. Guilford, New York (2011)

Yin, R.K.: Case Study Research: Design and Methods. Sage, Thousand Oaks, CA (2013)

Ziegler, R., Diehl, M.: Computer-supported idea generation. In: Rickards, T., Runco, M.A., Moger, S. (eds.) The Routledge Companion to Creativity. Routledge, New York, NY (2009)

Open Access This chapter is licensed under the terms of the Creative Commons Attribution 4.0 International License (http://creativecommons.org/licenses/by/4.0/), which permits use, sharing, adaptation, distribution and reproduction in any medium or format, as long as you give appropriate credit to the original author(s) and the source, provide a link to the Creative Commons license and indicate if changes were made.

The images or other third party material in this chapter are included in the chapter's Creative Commons license, unless indicated otherwise in a credit line to the material. If material is not included in the chapter's Creative Commons license and your intended use is not permitted by statutory regulation or exceeds the permitted use, you will need to obtain permission directly from the copyright holder. 